\title{
Hydrolysis of Polymeric Esters with Polymeric Sulfonic Acids
}

\section{Hydrolysis of Vinyl Acetate-N-Vinyl Pyrrolidone Copolymers}

By Ichiro Sakurada*, Yasuyoshi Sakaguchi** and Yasuhiro Omura*

\begin{abstract}
Vinyl acetate-N-vinyl pyrrolidone copolymers (VAc-VP) were hydrolyzed with polymeric sulfonic acids such as polystyrenesulfonic acid or low molecular sulfonic acids such as dodecylbenzene sulfonic acid, and the rate constants $\left(k_{s}\right)$ of the hydrolyses were compared with those of hydrolysis carried out under same condition using hydrochloric acid as a catalyst $\left(k_{\mathrm{HCl}}\right)$. Ratios of the rate constants, $r=k_{8} / k_{\mathrm{HC} 1}$ for the hydrolysis, which were generally greater than unity, were even greater than those for the hydrolysis of partially acetylated polyvinyl alcohols (Ac-PVA). Effects of acetyl content of the substrates, the structure of sulfonic acids and reaction mediums on $r$-value were less remarkable in the hydrolysis of VAc-VP than in the case of the hydrolysis of Ac-PVA. These results may be due to a greater binding tendency of VAc-VP in comparison with Ac-PVA to such sulfonic acids. The $r$-values of hydrolysis of allyl acetate-N-vinyl pyrrolidone copolymer (AAc-VP) were somewhat greater than those of hydrolysis of VAc-VP.
\end{abstract}

* Department of Polymer Chemistry, Kyoto University (Kyoto)

** Department of Applied Chemistry, Kōnan University (Higashinada-ku, Kōbe, Hyogo)

正誤訂正〔43〕水溶性ポリマー,ポリー（2-メチルスルフィニルーエチル）メタクリレートおよびポリー（2-メチルスル ホニルーエチル）メタクリレートの合成（大橋 カ，林 良之，小田良平：高化，24，334 (1967)]

\begin{tabular}{|c|c|c|}
\hline 所 & 誤 & 正 \\
\hline $\begin{array}{c}\text { 右段 } \\
\text { (上から } \\
\text { 行目) }\end{array}$ & 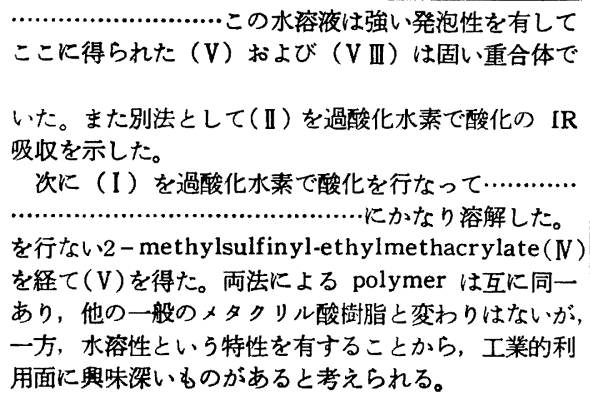 & 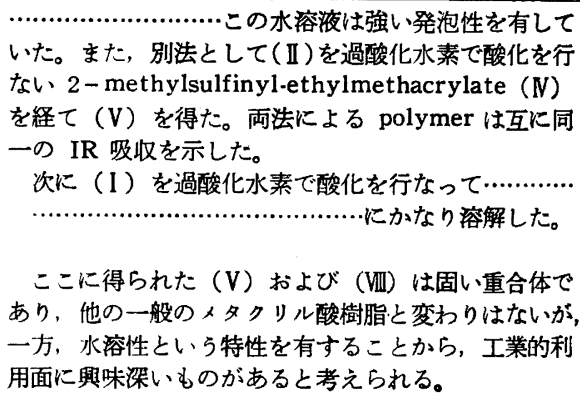 \\
\hline
\end{tabular}

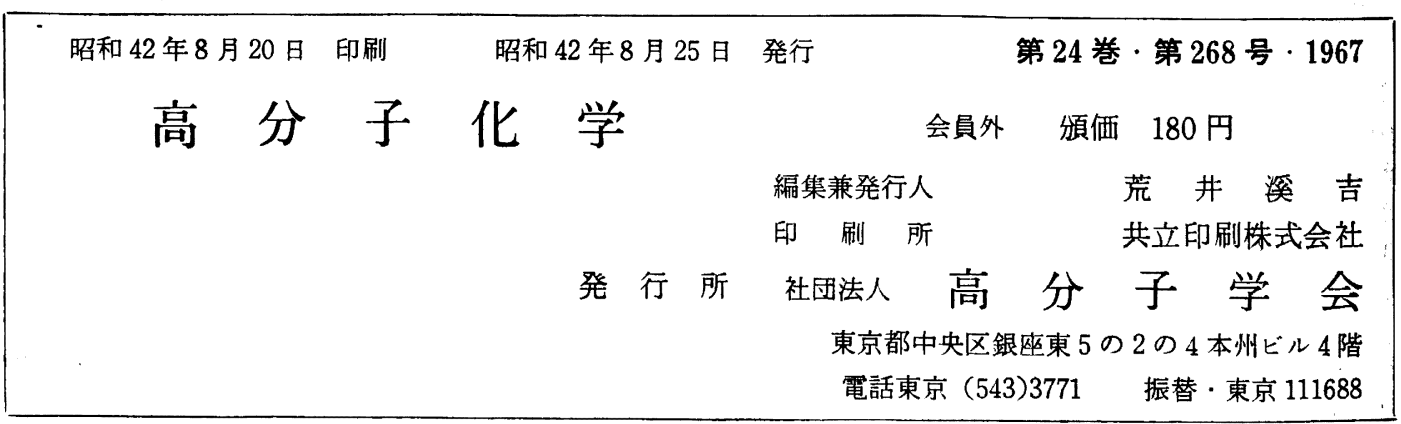

